\title{
Community forestry and livelihood linkages: A case of Kamalamai community forest, Dolakha, Nepal
}

\author{
Saroj Adhikari and Man Kumar Dhamala* \\ Central Department of Environmental Science, Kathmandu, Nepal
}

\begin{abstract}
As a result of institutional failure of the nationalization of forest in 1957 A.D., a newer concept of participatory forest management was introduced in Nepal and local people got their space created in forest management during 1970s with a view to mitigating forest cover loss. Under this scheme Kamalmai Community Forest (129.59 hectares) located in Laduk VDC of Dolakha District was handed over to the community in 2000 A.D. The present study was conducted during February, 2014 to assess the status of forest management strategies and impact on livelihood of forest dependent people. Management aspect of the forest was assessed based on field observation, Key Informant Interview and Focus Group Discussion, whereas judgmental scoring method was used to assess the impact on livelihood; the questionnaire for which was prepared on the basis of Sustainable Livelihood Framework Guidance Sheet developed by Department for International Development (DFID), 1999. All the forest management practices including control of composition and structure of growing stock, and harvesting and distribution of forest products were strictly implemented. The total average scores for human, physical, social, financial and natural capitals, which were used to assess the livelihood, were found to be $2.5862,1.4310,2.5689,0.2068$ and 2.6896 respectively. The result illustrated that the forest under study had contributed to enhance the condition of human, social and natural capitals. The contribution was noticeable in terms of physical capital, but financial capital was not found satisfactory. Since the handover, there has been a notable change in greenery and landscape as well as on livelihood of forest dependent people.
\end{abstract}

Key words: Capitals, Forest Management, Judgmental

\section{Introduction}

Nationalization of forests in 1957 transfer red the ownership of forest to the state regarding forests as important source of national economy, as not only private but also public goods (environmental functions and watershed value) were produced from forests. However, forest depletion and deforestation could not be controlled as the state could not enforce r ules regarding the management of forests (Kanel \& Dahal, 2008). As a result of institutional failure, a newer concept of participator y forest management was introduced in Nepal and local people got their space created in forest management only during 1970s with a view to mitigating forest cover loss.

Although, National Forestry Plan (NFP) of 1976 paved a way to incorporate local community in forest management, but could not provide any considerations to livelihood needs and also could not devolve any authority to local people, it too could not sustain (Acharya, 2002). In 1982, only af ter the enforcement of Decentralization Act, local communities were empowered, which

*Corresponding author, email address: mkdhamala@cdes.edu.np illustrates a tremendous shift from state-centric and top-down to community-based participatory approach of forest gover nance (Bhattacharya \& Basnyat, 2005)

In the early 1980s, mountains of Nepal were perceived as the site of double crisis (deforestation and poverty), thus affecting both the environment and livelihood at the local as well as regional level (Eckholm, 1976). Nepal Himalaya then became the matter of concern and inter national agencies began to invest a lot in terms of technical and financial support. Provision to form forest users group introduced in 1987 was a milestone for the community empowerment in Nepal (Kanel \& Dahal, 2008).

In Nepal, community Forestry (CF) program officially started in late 1970s. It involves the governance and management of forest resources by communities in collaboration with government and other stakeholders and was for mulated particularly to address local livelihood and abate environmental degradation through sustainable forest management (Gautam et al., 2008). Numbers 
of such community forest user groups have now reached to 18,133 in number, because of successful management history since handed over to local community (DoF, 2013). This has directly benefited more than 2,237,195 households.

The Master Plan for Forestry Sector (1989), Forest Act (1993), Forest Regulation (1995), Operational Guidelines (1995), and Tenth-Five Year Plan (2002-07) provide the legal and operational framework of Nepal's community forestr y (Pokharel \& Nurse, 2004). These have legitimized the concept of Community Forest User Group (CFUG) as an independent, autonomous and self governing institution responsible to protect, manage and use any patch of national forests with a defined forest boundary and user group members.

Livelihood comprises the capabilities, assets and activities required for a means of living. A livelihood is sustainable, when it can cope with and recovers from stress and shocks, maintains/enhances the capabilities and assets both at present and in future, while not undermining the natural resources base (DFID, 2000).

Community forestry program contributes to improve livelihood of r ural people by increasing the resources, by refor ming organizations, agencies and policies and facilitating the social changes (Pokharel, 2001). Forest condition, composition of user groups, decision making, and access to resources and distribution of benefits directly affect the people's livelihood (ICIMOD, 2004). The key concept is that people's access to forest and their involvement in decision making directly affects contribution of goods and benefits, and hence livelihood.

The management of forest by local depends on how much return they get from forest (Dev et al., 2004) which is related to livelihood enhancement through local people's involvement in forest management and benefit distribution as access to all five capitals (natural, social, human, financial and physical) is improved. Hence, forest management and livelihood are interrelated to each other and studies related to these are important to address future sustainability issues.

Nepalese CF has improved cohesion, which has direct and indirect impact on community development (Allison et al., 2004; Dev et al., 2004). The institution of the CFUG has a farreaching importance beyond forestry to rural communities and being a legally mandated institution with the potential to generate financial resources from forestry, the potentiality of the CFUG to ser ve as a broader community development institution at the local level is significant (Allison et al., 2004). Besides rural infrastructure development, CF has supported the needy households in case of illness, literacy program, social mobilization, income generation activities, saving, credit schemes (Dev et al., 2004), employment opportunity , supporting vulnerable households with provision of health funds, stretcher service (in hills) for community use, financial support to local school, salary to teacher, scholarship to children from low economic classes and infrastructural development (Chhetri, 2004; Sharma et al, 2004). In these contexts, this paper tries to assess the existing forest management practices and contribution of community forest on livelihood of forest dependent population in Kamalamai Community Forest (KCF), Dolakha.

\section{Materials and Methods Study area and data collection}

Dolakha, within Janakpur zone, is one of the seventy-five districts of Nepal located in central development region. The district, with Charik ot as its headquarters, covers an area of 2,191 km ${ }^{2}$ and has a population of 186,557 (CB S, 2011). The district is surrounded by Solukhumbu and Ramechhap districts in the east, Sindhupalchok and Kavrepalanchok districts in the west, China border in the north and Ramechhap district in the south. It extends between $27^{\circ} 28^{\prime}-28^{\circ} 05^{\prime}$ North latitude to $85^{\circ} 50^{\prime}-86^{\circ} 32^{\prime}$ East longitude and within an elevation range of $732-7134$ meters above sea level (Fig. 1). Dolakha experiences sub-tropical to temperate climate with an annual average rainfall of $1629.2 \mathrm{~mm}$ (DHM, 2013).

\section{Kamalamai Community Forest}

Kamalamai CF is located in Laduk Village Development Committee (ward no. 8) of Dolakha district covering a total area of 129.59 ha. There are 148 households directly depend on this CF . Geographically, it is located in South-East aspect and is a typical example of a mixed forest type with different species of the tress; the major ones being Pinus roxburghii, Schima wallichii, Alnus nepalensis, Syzygium cumini, Cleistocalyx operculatus and Engelhardia spicata (FOP, 2008).

Prior to 25 years, when the forest was a part of national forest, it was covered with dense vegetation, but with the increment in human settlement, the degradation rate was found very high, so it was handed over to the community in $2000 \mathrm{~A}$.D for the management and utilization. For the scientific management of the forest, the entire forest system has been divided into three sections based on timber production ability, regeneration status, topography, overall status of forest, soil fertility and forest conservation practices to be adopted (Fig. 2). The different sections include:

1. Section Ka: Poor, covering an area of 14.45 ha with average slope $30^{\circ}$

2. Section $K h a$ : Medium, covering an area of 78.39 ha and slope $10^{\circ}-35^{\circ}$

3. Section $G a$ : Good, covering an area of 38.35 ha and slope $5^{0}-35^{\circ}$

\section{能X TU-CDES}




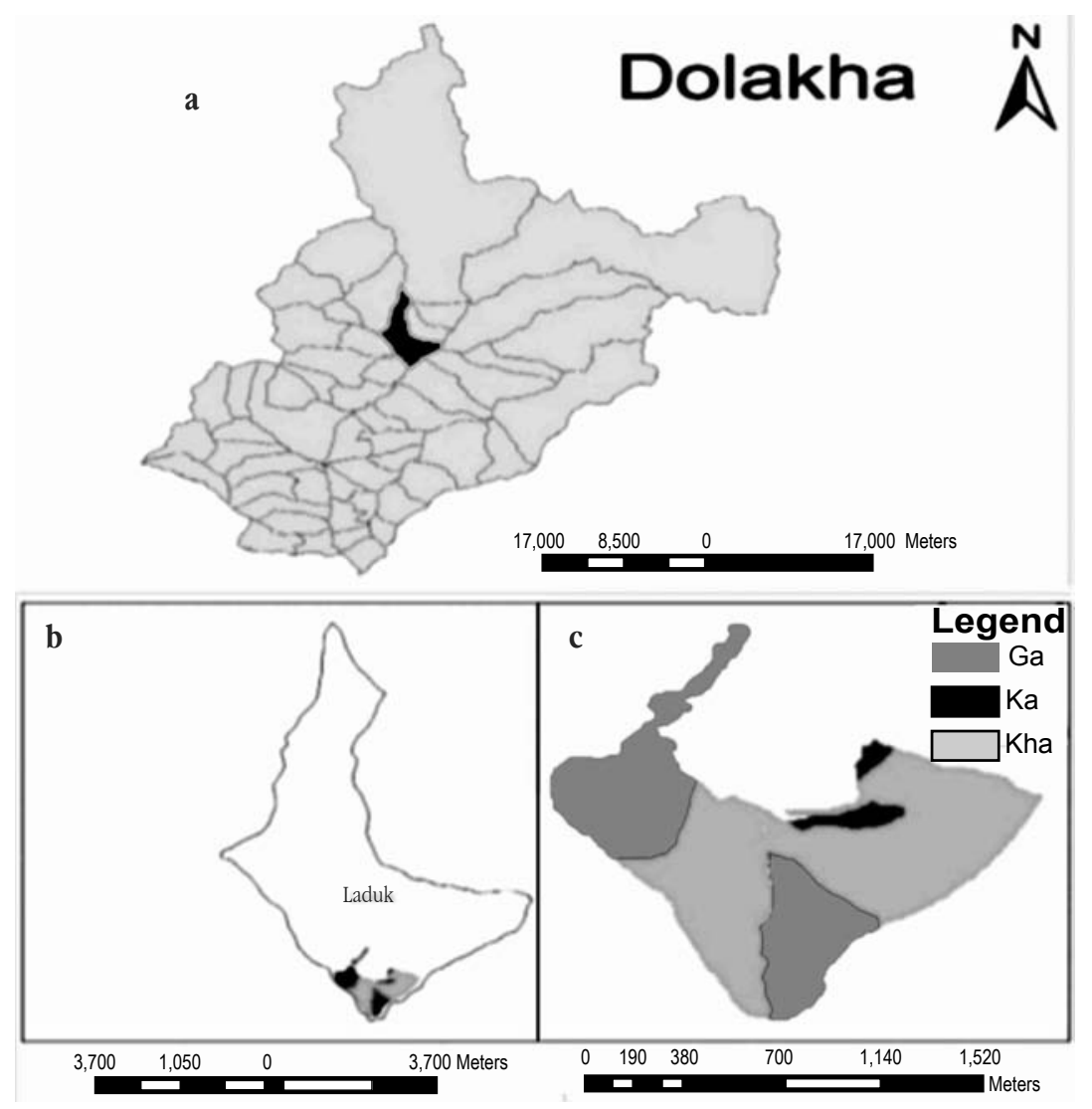

Figure 1 Study Area a. Location in Dolakha District, b. Laduk VDC, C. Kamalamai Community Foresty

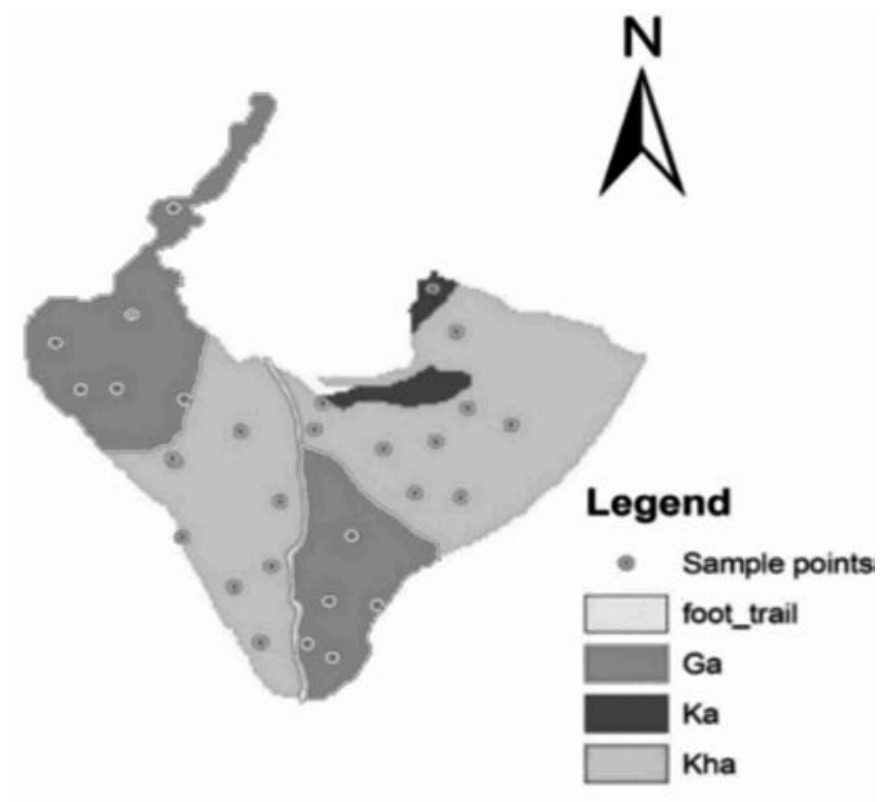

0150006009001,200

\section{Meters}

Figure 2 Kamalamai community forest showing sample points 
Both the primary and secondary data relevant to the study were collected using different community participatory tool as well as statistical approaches. Of the total 148 households in the study area, a sample of 58 households were sur veyed to assess the contribution of community forestry on livelihood of the people. Sample size was determined based on the formula given by Arkin and Colton (1963).

$$
\text { Sample size, } n=\frac{N x Z^{2} p(1-p)}{N x d^{2}+Z^{2} p(1-p)}
$$

Where,

$$
\begin{aligned}
& n=\text { Sample Size } \\
& N=\text { Total number of households } \\
& Z=\text { Value of variance at } 95 \%(1.96) \\
& d=\text { Acceptable error }(10 \%) \\
& p=0.5
\end{aligned}
$$

Household survey was conducted to collect the information about different variables like demography, education, caste, occupation, sources of income which was based on the open ended questionnaire. In addition to the demographic variables, the information about the status of five different livelihood capitals (natural, physical, social, financial and human) in the study area were also collected in order to assess the contribution of community forest on livelihood of the forest user populations. Various indicators used for the assessment of livelihood capitals are presented in Table 1.
Check lists for KII and FGD were prepared and informal interviews were conducted with key informants, whereas a group discussion was done with the members of user group like mother's group, teacher, chairperson of the $\mathrm{CF}$, representative from lower caste in order to collect the infor mation in detail about the status of community forest including the cur rent management practices adopted and secondary data were collected from different relevant published and unpublished literatures. Data for forest cover and forest profile were collected from District Forest Office Dolakha, VDC profile, Community forest profile from $\mathrm{F}$ ederation of Community Forest Users Nepal (FECOFUN), operational plan for Kamalamai Community F orest (K CF) was obtained from Gaurishankar Conservation Area head office, L aduk and other related CFUG records.

\section{Livelihood assessment through sustainable livelihood framework}

For the assessment of the contribution of the community forestry in the livelihood of forest user population, sustainable livelihood framework developed by Institute of Development Studies (IDS) and later modified by DFID in 1999 was used. Assessment was based on the judgmental scoring methods, where changes in five different capitals (human, physical, social, financial and natural) after the handover of the forest were calculated based on fifteen different indicators (Table 1 ). Three scores viz. $+1,-1$ and 0 were assigned to assess the improvements, degradation and no changes in the conditions of each of the indicators used for five capitals (Table 1).

Table 1 Indicators used for the assessment of livelihood capitals

\begin{tabular}{ll}
\hline Livelihood Capitals & Indicators used \\
\hline Natural Capital & $\begin{array}{l}\text { i. Amount of forest product collection after handover of CF } \\
\text { ii. Incidences of drying up of water resources } \\
\text { iii. Improvement in greenery and landscape beauty }\end{array}$ \\
Physical Capital & $\begin{array}{l}\text { i. Construction and access to physical capital } \\
\text { ii .Effectiveness of construction }\end{array}$ \\
Social Capital & iii. Enhancement of knowledge regarding community development activitie \\
Financial Capital & $\begin{array}{l}\text { ii. Delation among user groups after handover of CF } \\
\text { iii. Major role played in decision making }\end{array}$ \\
& $\begin{array}{l}\text { i. Increment in employment opportunities } \\
\text { ii. Time and cost required for forest products collection }\end{array}$ \\
Human Capital & iii. Provisions of loan for IGAs \\
& $\begin{array}{l}\text { i. Condition of awareness regarding responsibilities among user groups } \\
\text { ii. State of skills and knowledge on forest management } \\
\text { iii. Changes in leadership capacity }\end{array}$ \\
\hline
\end{tabular}

Source: DFID (1999) 
The total values of the capitals were plotted in a spider web diagram (Fig. 3), the shape of the pentagon obtained gives the variation in people's access to each of the capitals (Chapagain, 2007). Access to capitals is based on the idea that the central point of the pentagon represents no access to any of the capitals, whereas the outer boundary represents maximum access (Poudel, 2004).

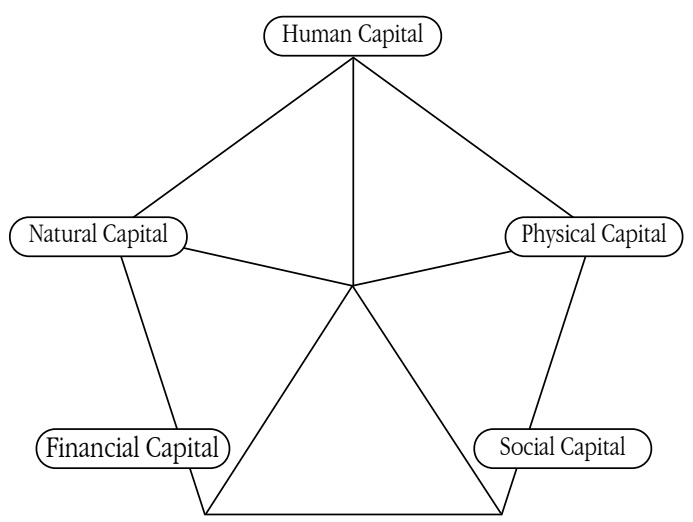

Figure 3 Livelihood Pentagon

\section{Results and Discussion}

\section{Current status of forest management}

The several forest management activities performed by Kamalamai CFUG are explained as follows:

1. Silviculture which involves weeding, thinning, and pruning; as a management of growing stock was per formed every year from Januar y to May, which contributed to forest management in addition to the availability of fodder and fuel-wood. Similarly, clearance of forest floor was performed from May to September, so that the incidences of forest fire could be reduced together with the availability of bedding materials for cattle.

2. Plantation was another management options people followed in the forest. Since the handover of the forest to the community, plantation has been done for six times. Plantation was usually done in the areas where transmission lines were established.

3. Fire line with a diameter of $3 \mathrm{~m}$ has been constr ucted to reduce the spread of forest fire and it is cleaned ever y two years.

4. Timber harvested from the forest is distributed among the users for construction of new houses and for the repair of the worn out houses. For construction purpose, 60-70 cubic feet of timber was distributed, whereas only 20-25 cubic feet for repairing worn out houses. Likewise, 220 cubic feet of fire wood per household is distributed every year and users have to pay Rs.40/cubic feet for timber and Rs.10/cubic feet for firewood, which is deposited in the fund.

5. The fund is invested as rotational fund. The fund is made available for six months for the household requiring it, at $10 \%$ interest rate. It is also invested in several sectors lik e education (schools), health (ambulance), and in income generating activities like poultry farming, animal (cattle) husbandry and providing training in skills enhancement like knitting.

Forest management occurs over a cycle of decision and events designated as rotation. The main objective of forest management should be to develop and implement an integrated program of resource management, including watershed management and biodiversity conservation. Acharya (2003) explains that management of forest involves following three processes:

1. Control of composition and structure of growing stock

2. Harvesting and distribution of forest products, and

3. Administration of forest property and personnel

\section{Community forest and status of livelihood capitals}

The status of livelihood capitals in the study area was assessed through the judgmental scoring method, in which the changes brought about in five different capitals after the handover of the forest to the community. The changes in each capital were studied on the basis of three indicators for each capital. The average scores were then plotted in a spider web diagram (Fig. 4)

The indicators used to assess human capitals were condition of awareness regarding responsibilities among user groups, state of skills and knowledge on forest management and changes in leadership capacity, each of which got the average scores of 0.8793 , 0.8793 and 0.8275 respectively. The total score for the human capital was found to be 2.5862 . Similarly, the physical capital was assessed based on indicators lik e construction and access to physical capitals, effectiveness of construction and enhancement of knowledge regarding community development activities. The average scores for each of these indicators were found to be $0.6379,0.0517$ and 0.7413 respectively. The total score for physical capital was 1.4310 .

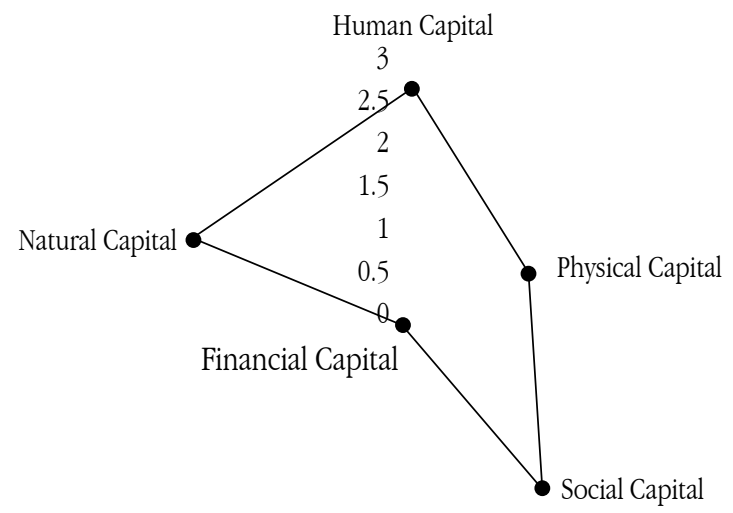

Figure 4 Community forest and status of livelihood capitals 
Relation among the user groups af ter handover of $\mathrm{CF}$, decision making capacity about resources management and use and major role played in decision making were the indicators used to assess the social capital and the average score for each of these indicators were $0.9482,0.8448$ and 0.7758 respectively. The total score for social capital was 2.5689. Lik ewise, among the three indicators used to assess the status of financial capitals, increment in employment opportunities got an average score of -0.1379 , time and cost required for forest products collection 0.5517 and provisions of loan for income generating activities (IGAs) - 0.2068 The total score for this capital was 0.2068 .

The amount of forest product collection af ter handover of CF, incidences of drying up of water resources and improvement in greenery and landscape beauty were used as indicators to assess the status of natural capitals and each of these had the average scores of $0.8965,0.8620$ and 0.9310 respectively. The total score for this capital was 2.6896 .

The result illustrated that after handover to the community, the forest had positively contributed to enhance the condition of human, social and natural capitals. The contribution was noticeable in terms of physical capital, but the condition of financial capital was poorer. This condition of financial capital may also have some implications to the sustainability of forest and forest products (Jackson \& Ingles, 1995).

\section{Conclusion}

Kamalamai community forest was found to have a positive effect on livelihood of the people. The most noticeable achievement was reduction of forest degradation and improvement in greenery of the landscape. All the forest management practices including control of composition and str ucture of growing stock and harvesting and distribution of forest products were strictly implemented and people were found to be actively involved in these management activities as they were getting the regular flow of the products for their daily needs in a sustainable basis which has contributed to enhance their livelihood. Kamalamai Community Forest was found to be contributing to the local livelihoods through the better flow of forest products and development of livelihoods assets in the grassroots level.

\section{Acknowledgements}

The authors would like to acknowledge Central Department of Environmental Science, Tribhuan Univerwity for providing the financial support to conduct this research. Authors are also grateful to the officials of Department of Forest, Kathmandu for data source and the locale of Laduk VDC for their support during the field visit.

\section{References}

Acharya, K.P. (2002). Twenty-four years of community forestry in Nepal, International Forestry Review 4(2): 149-56.
Acharya, K.P. (2003). Conserving biodiversity and improving livelihoods: the case of community forestry in Nepal. Paper presented at International Conference on Rural Livelihood, Forest and Biodiversity, Bonn, Germany.

Allision, G.,Bampton, J.,Kandel, B.R.,Shrestha, M. L., \& Shrestha, N. K. (2004). "'d2Community Forestry and Livelihoods: How Can Community Forestry Better Contribute to the Millennium Development Goals in Nepal?" Twenty Five Years of Community Forestry, Proceeding of Fourth National Community Forestry Workshop, Department of Forest ( DoF), Community Forestry Division ( CFD) , Kathmandu.

Arkin, H., \& Colton, R.(1963). Table for statistics. New York: Barnes and Noble Publication.

Bhattacharya, A.K., \& Basnyat, B. (2005). Decentralization and Community Forestry Programmes in Nepal: Issues and Challenges, International Forestry Review 7, 147-155.

CBS (2011). National Population and Housing Census. Central Bureau of Statistics, Government of Nepal, Kathmandu.

CFD (2013). Community Forest Division, Department of Forest, Babarmahal, Kathmandu, Nepal.

Chapagain, B.P. (2007). Impact of Community Forestry on Livelihood Improvement of Rural People (A Case Study of Shirkhola CFUG, Maisthan, Mahottari). B. Sc. Thesis. Institute of Forest, Hetauda Campus, Hetauda, Nepal.

Chhetri, B.B.K. (2004). Community Forestry Programmes in the Hills of Nepal: Determinants of Users Participation and Household Dependency. M.Sc. Thesis, Norwegian University of Life Science (UMB).

Dev, O.P., Baginski, O.S., \&Karn, A.K. (2004). Understanding Livelihood Impact of Participatory Forest Management Implementation Strategy in Nepal. In K.R. Kanel et al. (Eds.), Twenty Five Years of Community Forestry, Proceeding of Fourth National Community Forestry, Workshop, Department of Forest ( DoF), Community Forestry Division ( CFD), Kathmandu. DFID (1999). Sustainable Guidance Sheets Framework. Department for International Development (DFID), London, UK.

DFID (2000). Sustainable Guidance Sheets Framework. Department for International

Development(www.livelihood.org/info/info_guidancesheets. html).

DOF (2013). Community forestry user groups database. Community Forestry Division, Department of Forest (DOF), Kathmandu, Nepal.

Eckholm, E. P. (1976). Losing Ground: Environmental Stress and World Food Prospects World Watch Institute, USA.

Gautam, A.P., Karmacharya, M.B., \& Karna, B.K.(2008). Community Forestry, Equity and Sustainable Livelihoods in Nepal.

Gautam, A.P., Shivakoti, G.P., \& Webb, E.L. (2004).A review of forest policies, institutions, and changes in the resource condition in Nepal, International Forestry Review6, 136-48.

Gurung, A., Karki, R., \& Bista, R. (2011). Community-Based Forest Management in Nepal: Opportunities and Challenges.Resources and Environment 1(1): 26-31. 
ICIMOD (2004). Biodiversity and Livelihoods in Hindu-Kush Himalayan Region. International Centre for Integrated Mountain Development (ICIMOD) Newsletter No. 45. ICIMOD, Kathmandu, Nepal.

Jackson, W.J., \& Ingle, A.W. (1995).Developing Rural Community and Conserving the Biodiversity of Nepal's Forest through Community Forestry. In H. Wood et al., (Eds.) Community Development and Conservation of Forest Biodiversity through Community Forestry. Proceedings of a Seminar (pp. 26-28). Bangkok, Thailand.

Kanel, K.R., \& Dahal, G.R. (2008). Community Forestry Policy and its Economic Implications: An Experience from Nepal. International Journal of Social Forestry 1(1):50-60.

Odihi, J.(2003). Deforestation in Afforestation Priority Zone in Sudano-Sahelian Nigeria, Application Geography 23, 227-59.

Ojha, H., \& Kanel, K.(2005). 25 Years of Community Forestry in Nepal: A Review of Fourth National Workshop Proceedings. Journal of Forest and Livelibood 4(2): 23-27.
Pokharel, B.K. (2001). Livelihoods, economic opportunities and equity (http://www.livelihoods.org/post/forest1-postit.html.) Pokharel, B.K., \& Nurse, M. (2004). Forests and Peoples' Livelihoods: Benefittingthe Poor from Community Forestry. Journal of Forest and Liveliboods 4(1): 19-29.

Poudel, K.N. (2004). Contribution of Community Forestry on Rural Livelihood of Disadvantaged Groups in Baglung and Kaski Districts. Master's Thesis. Central Department of Sociology, TU, Kirtipur Nepal.

Sharma, B.D.,Karky. B.S., Dahal. N., Chapagain, N., \& Basnet, K. (2004).Prospects and Challenges in Bringing Nepal's Community Forestry under Kyoto Protocol's Carbon Trading Regime in Nepal. In K.R. Kanel et al. (Eds.)Twenty Five Years of Community Forestry, Proceeding of Fourth National Community Forestry Workshop, Department of Forest ( DoF), Community Forestry Division ( CFD) , Kathmandu. 